\title{
Open Access Journal of
}

Addiction and Psychology

\section{World Youth Day}

\author{
Gabriel Miranda Nava* \\ Chief of Neurology of the Hospital Center of the Presidential General Staff, Mexico
}

*Corresponding author: Gabriel Miranda Nava, Chief of Neurology of the Hospital Center of the Presidential General Staff, Mexico.

\section{Opinion}

Now that the world's day of youth is celebrated, August 12, it is well worth understanding what it means to be young medically. When you leave behind primary education, a series of biological changes begin that invade us in a terrible way, be it sleeping habits, the way of relating to parents, the way we feed ourselves, the changes of our sexual organs (changes) as they begin the first sexual desires, the doubts about menstruation, masturbation, and in many cases the first sexually transmitted diseases or unplanned pregnancies.

Many times, when we see a teenager irritable, annoying, reactive or aggressive, we immediately have the magic response that gives us peace of mind and takes away the responsibility and effort to investigate what is happening, this concept being as wrong as the changes that are made to him. attributed to menopause in women.

Is a depression hidden?

Does this behavior coincide with an intake of illicit drugs?

Is poor school performance natural and expected for a teenager?
In no way, since a bad sleep, terrible habits, extreme irritations or so palpable mood swings are negative at any age, we should not blame this phenomenon unless we have been certain we have not found another cause, because that by that so basic and clumsy reasoning potential addictions or sociopathic behavior hide, and it is no coincidence that usage statistics of narcotics in Mexico have the highest incidence peaks between 13 and 21 years, like pregnancies truly desired young women, almost children, or that the virus in mounded human iciencia increasingly look at younger and younger patients due to lack of information or care. We have to take care of our children, our young people, each stage is very important, there is not one more than another, and not to leave the explanation so primary and pilgrim that "... is the age ..." because we can take so many surprises.

\section{Acknowledgement}

None.

\section{Conflict of Interest}

No conflict of interest. 